\title{
Patterns of hepatitis B virus infection in Brazilian human immunodeficiency virus infected patients: high prevalence of occult infection and low frequency of lamivudine resistant mutations
}

\author{
Michel VF Sucupira, Francisco CA Mello, Eneida A Santos, Christian Niel, Valeria C Rolla*, \\ Juçara Arabe**/++, Selma A Gomes/ ${ }^{+}$
}

Departamento de Virologia, Instituto Oswaldo Cruz-Fiocruz *Instituto de Pesquisa Clínica Hospital Evandro Chagas-Fiocruz, Av. Brasil 4365, 21040-900 Rio de Janeiro, RJ, Brasil **Hospital Universitário Gaffrée e Guinle, Rio de Janeiro, RJ, Brasil

Hepatitis $B$ virus (HBV) molecular profiles were determined for 44 patients who were infected with human immunodeficiency virus (HIV) type 1 and had antibodies to the hepatitis $B$ core antigen (anti-HBc), with and without other $H B V$ serological markers. In this population, $70 \%$ of the patients were under lamivudine treatment as a component of antiretroviral therapy. HBV DNA was detected in 14 (32\%) patients. Eight out of 12 (67\%) HBsAg positive samples, 3/10 (30\%) anti-HBc only samples, and 3/22 (14\%) anti-HBs positive samples were HBV DNA positive. HBV DNA loads, measured by real time polymerase chain reaction, were much higher in the HBsAg positive patients (mean, $2.5 \times 10^{9}$ copies $/ \mathrm{ml}$ ) than in the negative ones (HBV occult infection; mean, $2.7 \times 10^{5}$ copies $/ \mathrm{ml}$ ). Nine out of the 14 HBV DNA positive patients were under lamivudine treatment. Lamivudine resistant mutations in the polymerase gene were detected in only three patients, all of them belonging to the subgroup of five HBsAg positive, $H B V D N A$ positive patients. A low mean $H B V$ load $\left(2.7 \times 10^{5}\right.$ copies $\left./ \mathrm{ml}\right)$ and an absence of lamivudine resistant mutations were observed among the cases of $H B V$ occult infection.

Key words: hepatitis B virus - human immunodeficiency virus - lamivudine - drug resistance - mutations

Hepatitis B virus (HBV) is the prototype member of the Hepadnaviridae family that causes acute and chronic liver disease including cirrhosis and hepatocellular carcinoma. HBV infection is a global public health problem with more than 300 million HBV carriers in the world. HBV infection is commonly diagnosed by the presence of hepatitis B surface antigen ( $\mathrm{HBsAg}$ ) and antibodies to the hepatitis B core antigen (anti-HBc). Anti-HBc usually appears in the acute phase of $\mathrm{HBV}$ infection and persists for a long time after virus clearance. Simultaneous presence of HBsAg and anti-HBc reveals a current infection. The presence of anti-HBs with anti-HBc usually indicates a past, resolved infection. The presence of anti-HBc alone is often interpreted as evidence of past HBV infection with undetectable levels of anti-HBs. Anti-HBc alone may also indicate undetectable levels of HBsAg in the blood of an HBV chronic carrier (Medrano et al. 1991).

Detection of HBV DNA without detectable HBsAg is defined as occult HBV infection (Brechot et al. 2001, Conjeevaram \& Lok 2001). The frequency of detection of occult HBV infection depends on the relative sensitivity

\footnotetext{
Financial support: Faperj, CNPq

${ }^{+}$Corresponding author: selma@ioc.fiocruz.br

${ }^{++}$Present adress: Instituto de Pesquisa Clínica Hospital Evandro Chagas-Fiocruz.

Received 24 March 2006

Accepted 5 July 2006
}

of both HBsAg and HBV DNA assays. It also depends on the prevalence of $\mathrm{HBV}$ infection in the population (Allain 2004). The role of occult HBV infection in the etiology of liver disease is still unclear. However, there is clear evidence that transmission of HBV by HBsAg-negative material occurs (Allain 2004). A key question for understanding the role of occult infection is whether the presence of small amounts of HBV will lead to progressive liver disease. Regular measurement of HBV DNA loads in serum should define the lowest level of HBV DNA below which $\mathrm{HBV}$ is inactive and not transmissible. To address this question, standards for HBV quantification have been developed (Niesters et al. 2000).

In patients co-infected with HBV and human immunodeficiency virus (HIV), it has been suggested that HIV interferes with the natural history of HBV infection by enhancing HBV replication, leading to more severe liver disease, decreased hepatitis $\mathrm{B}$ e antigen seroconversion and higher HBV DNA levels. Furthermore, end-stage liver disease has emerged as a common cause of morbidity and mortality of patients infected with HIV in response to immunological reconstitution after antiretroviral therapy (Thio 2004).

HBV is classified into eight genotypes (A-H) with distinct geographical distribution. In Japan, a different distribution of HBV genotypes has been reported in HIVinfected and HIV-negative populations (Koibuchi et al. 2001). In Brazil, where genotypes A, D, and F are the most prevalent, a similar distribution of genotypes between HIV infected and non infected patients has been observed (Niel et al. 1994, Moraes et al. 1996, Araujo et al. 2004, Santos et al. 2004). 
Lamivudine is a nucleoside analogue that inhibits the reverse transcriptase activity of both HIV and HBV (Benhamou et al. 1996). This drug is widely used as part of the treatment of HIV infection and has also been used in the treatment of HBV infection (Dienstag et al. 1995, Lai $\&$ Yuen 2000, Leung 2004). The serum HBV DNA decrease due to lamivudine treatment is frequently accompanied by significant histological and biochemical improvement (Loriot et al. 1992). The major limitation in the use of lamivudine is the selection of resistant mutations, which affect the YMDD motif of the HBV DNA polymerase. The resistance in the YMDD motif occurs by replacement of the methionine residue at position 550 by either valine (M550V) or isoleucine (M550I). The M550V variant may be accompanied by a mutation that changes leucine into methionine at residue 526 (L526M) (Lai \& Yuen 2000, Leung 2004). Such mutations have notably been reported in studies performed with HIV-HBV co-infected patients (Dore et al. 1999, Thibault et al. 1999, Hoff et al. 2001). More than $90 \%$ of the HIV-HBV co-infected patients under lamivudine treatment display the double resistant mutation L526M and M550V (Thibault et al. 1999). The simultaneous presence of L526M and M550V mutations seems to be associated with prolonged lamivudine treatment(Yeh et al. 2000).

Here we investigate the prevalence of HBV DNA and viral load variations in patients displaying different $\mathrm{HBV}$ serological patterns in a group of HIV infected patients. We characterize HBV strains derived from HIV infected patients receiving lamivudine as a component of antiretroviral therapy and determine the frequency of lamivudine resistance mutations.

\section{MATERIALS AND METHODS}

Patients and serological studies - The study group consisted of 44 HIV-1 infected subjects (mean age, 38 years) who were anti-HBc positive with or without other HBV serological markers and who attended as outpatients at two public hospitals (Gaffrée e Guinle and Evandro Chagas) in Rio de Janeiro, Brazil, between 2000 and 2004. The protocol used was approved by the Ethical Committee of Oswaldo Cruz Foundation. Participants were randomly selected and informed consent was obtained from all of them. All patients were anti-HIV-1 positive by conventional serological tests and belonged to different risk groups for HIV infection. All patients were asymptomatic for $\mathrm{HBV}$ infection. In 31 patients, lamivudine was administered as part of antiretroviral treatment. Serum samples from all patients were initially tested for anti-HBc, HBsAg, and anti-HBs in the hospitals. These samples were not available, and new blood samples were collected from all 44 patients, retested for the presence of $\mathrm{HBsAg}$, anti-HBc, and anti-HBs by enzyme-linked immunosorbent assay (Hepanostika Uni-form Organon Teknika B.V., Boxtel, Holland) and further used for genomic studies.

$D N A$ extraction and real time PCR - HBV DNA was extracted from serum by using phenol-chloroform after treatment with proteinase $\mathrm{K}$, as reported previously (Niel et al. 1994). A panel of reference sera with known numbers of HBV DNA molecules, kindly supplied by Dr. Ikuta (Universidade Luterana, Canoas, Brazil), was used for quantification by real time PCR. This was done using TaqMan technology, according to Pas and Niesters (2002) with some modifications. Amplification assays were performed in a final volume of $25 \mu \mathrm{l}$ of TaqMan universal MasterMix (Applied BioSystems, Foster City, CA, US), containing $2 \mu \mathrm{l}$ of extracted DNA, $1 \mu \mathrm{M}$ of each primer (sense, 5'-GGACCCCTGCTCGTGTTACA-3', nucleotide position 184 to 203, and antisense, 5'-AGAGAAGTCC ACCMCGAGTCTAGA-3', nucleotide position 273 to 249), and $0.3 \mu \mathrm{M}$ of probe 5 '-FAM-TGTTGACAARAATCCT CACAATACCRCAGA-TAMRA-3', nucleotide position 218-247. After an initial incubation step of $2 \mathrm{~min}$ at $50^{\circ} \mathrm{C}$, and $10 \mathrm{~min}$ at $95^{\circ} \mathrm{C}$, the $\mathrm{PCR}$ cycling program consisted of 50 step cycles of $15 \mathrm{~s}$ at $95^{\circ} \mathrm{C}$ and $60 \mathrm{~s}$ at $60^{\circ} \mathrm{C}$. Reactions were performed in a 7700 SDS system (Applied BioSystems). The assay has a limit of detection of 10 copies/ reaction or about 100 copies $/ \mathrm{ml}$ of serum.

Nucleotide sequencing - Samples positive by real time polymerase chain reaction (PCR) were submitted to amplification using semi-nested PCR assays. Pre-S/S region was first amplified with external primers PS1 (5'CCATATTCTTGGGAACAA GA-3', nt 2826-2845) and a mix of antisense primers S2 (5'-GGGTTTAAATGTATAC CCAAAGA-3', nt 841-819) and S22 (5'- GTATTTAAA TGGATACCCACAGA-3', nt 841-819), which amplify HBV DNA from all genotypes. The second round was performed using sense primer PS4 (5'-CATCCTCAGGCC ATGCAGTG-3', nt 3199-3218) and antisense primers S2/ S22. PCR assays were performed with $1 \mu$ of DNA in a final volume of $50 \mu 1$ under the following conditions: $94^{\circ} \mathrm{C}$, $30 \mathrm{~s} ; 52^{\circ} \mathrm{C}, 1 \mathrm{~min} ; 72^{\circ} \mathrm{C}, 2 \mathrm{~min} ; 35$ cycles, followed by a final elongation of $7 \mathrm{~min}$ at $72^{\circ} \mathrm{C}$. Amplification products $(50 \mu \mathrm{l})$ were loaded on a $2 \%$ agarose gel, electrophoresed, stained with ethidium bromide, and visualized under UV light. DNA bands were extracted from the agarose gels and nucleotide sequences were determined using BigDye Terminator kit (Applied Biosystems) with specific internal HBV primers. Sequencing reactions were analyzed on an ABI373 automated sequencer (Applied Biosystems). Bioinformatic analysis of the sequences was performed applying the University of Wisconsin Genetic Computer Group package.

\section{RESULTS}

$H B V$ serological patterns and clinical characteristics of HIV-1-infected, anti-HBc positive patients - Among 44 HIV-1 infected patients (32 male, 12 female) who were positive for anti-HBc, 27 (61\%) belonged to sexual behavior risk groups for HIV infection. Twenty-four out of the 32 men $(75 \%)$ were homosexual or bisexual. Three out of $12(25 \%)$ women declared having a sexual partner infected with HIV (Table I). Risk factor for HIV infection was unknown for 13 (30\%) patients. Forty (91\%) patients were under antiretroviral treatment, and only five (11\%) had CD4 levels lower than $200 \times 10^{6} / 1$. Even so, twenty (45\%) patients were classified as having AIDS due to previous notification of an AIDS associated disease. Among the 40 patients under antiretroviral treatment, 31 (77.5\%) received lamivudine as part of this antiretroviral therapy. Twelve (27\%) patients were HBsAg positive, $22(50 \%)$ were anti- 
HBs positive, and $10(23 \%)$ had anti-HBc as the sole $\mathrm{HBV}$ serological marker.

Detection of HBV DNA and viral load determination by real time $P C R$ - Serum samples from all patients were tested for HBV DNA by real time PCR amplification; 14 (32\%) samples were positive (Table II). HBV DNA was detected in 8/12 (67\%) HBsAg positive samples, $3 / 10(30 \%)$ 'anti-HBc alone' samples, and 3/22 (14\%) anti-HBs positive samples. Viremia varied from $9.0 \times 10^{6}$ to $6.6 \times 10^{9}$ copies $/ \mathrm{ml}$ (mean, $2.5 \times 10^{9}$; median, $3.5 \times 10^{9}$ ) among the HBsAg positive patients, from $2.2 \times 10^{4}$ to $1.2 \times 10^{6}$ among 'anti-HBc alone', and from $1.2 \times 10^{4}$ to $3.2 \times 10^{5} \mathrm{copies} / \mathrm{ml}$ among anti-HBs positive patients. In summary, among HBsAg negative patients the mean viral load was $2.7 \times$ $10^{5}$ copies $/ \mathrm{ml}$ (median $\left.4.0 \times 10^{4}\right)$. The difference between the mean viral load of the HBsAg positive and negative patients was highly significant $(\mathrm{p}<0.0001)$. As indicated above, most patients were receiving an anti-HIV regimen including lamivudine (Table I). Among them, 9 (29\%) were HBV DNA positive (Table II). This proportion was not significantly different from that $(5 / 13,38 \%)$ found among patients not submitted to lamivudine therapy.
Analysis of nucleotide and amino acid sequences of the $S$ region - Nucleotide sequences (complete S region, overlapping polymerase gene) of 13/14 HBV DNA positive samples were determined. Phylogenetic analysis showed that nine $\mathrm{HBV}$ isolates belonged to genotype A, subtype $\mathrm{Aa}$, and that the four others belonged to genotype $\mathrm{D}$ (not shown). Among these 13 isolates, eight were from patients under lamivudine treatment (duration 11-60 months; Table II). The deduced polymerase amino acid sequences showed that, despite the long period of lamivudine administration, only three isolates (patients 3 , 4 , and 12) showed the double L526M and M550V resistance mutation (Table III). One of them (patient 12) showed an additional mutation (V519L), which has also been related to lamivudine resistance (Torresi et al. 2002). Isolates 3, 4, and 12 belonged to genotype A, subgroup Aa. All three were derived from HBsAg positive patients. The isolates from the other patients under lamivudine (two HBsAg positive and four HBsAg negative) did not show resistance mutations. Patients infected with isolates carrying lamivudine resistance mutations had HBV loads varying from $6 \times 10^{8}$ to $6.6 \times 10^{9}$ copies $/ \mathrm{ml}$ (Table III). Lower values $\left(2.2 \times 10^{4}\right.$ to $2 \times 10^{7}$ copies $\left./ \mathrm{ml}\right)$ were found

TABLE I

Demographical, serological, and clinical data of the patients

\begin{tabular}{|c|c|c|c|c|}
\hline Patient characteristics & $\mathrm{HBsAg}$,anti-HBc & Anti-HBs, anti-HBc & Anti-HBc alone & $n(\%)$ \\
\hline \multicolumn{5}{|l|}{ Sex } \\
\hline Male & 11 & 12 & 9 & $32(73)$ \\
\hline Female & 1 & 10 & 1 & $12(27)$ \\
\hline \multicolumn{5}{|l|}{ Age (years) } \\
\hline$<30$ & 1 & 3 & - & $4(9)$ \\
\hline $30-49$ & 9 & 18 & 7 & $34(77)$ \\
\hline$>49$ & 2 & 1 & 3 & $6(14)$ \\
\hline \multicolumn{5}{|l|}{ Risk group } \\
\hline Homo/bisexual men & 8 & 10 & 6 & $24(54)$ \\
\hline $\mathrm{HIV}^{+}$partner $^{a}$ & - & 3 & - & $3(6.8)$ \\
\hline IVDU & 1 & - & 1 & $2(4.6)$ \\
\hline Transfusion & 2 & - & - & $2(4.6)$ \\
\hline Unknown & 1 & 9 & 3 & $13(30)$ \\
\hline \multicolumn{5}{|l|}{ HIV status } \\
\hline AIDS & 6 & 12 & 2 & $20(45)$ \\
\hline Asymptomatic & 6 & 10 & 8 & $24(55)$ \\
\hline \multicolumn{5}{|l|}{ CD4 cell counts $\left(10^{6} / 1\right)$} \\
\hline$<200$ & 1 & 2 & 2 & $5(11)$ \\
\hline $200-499$ & 6 & 13 & 6 & $25(57)$ \\
\hline$>500$ & 5 & 7 & 2 & $14(32)$ \\
\hline \multicolumn{5}{|l|}{ Antiretroviral treatment } \\
\hline Yes & 11 & 20 & 9 & $40(91)$ \\
\hline No & 1 & 2 & 1 & $4(9)$ \\
\hline \multicolumn{5}{|l|}{ Lamivudine } \\
\hline Yes & 8 & 16 & 7 & $31(70)$ \\
\hline No & 4 & 6 & 3 & $13(30)$ \\
\hline Total & 12 & 22 & 10 & $44(100)$ \\
\hline
\end{tabular}

$a$ : women having an HIV infected sexual partner; IVDU: intravenous drug user; HBsAg: hepatitis B surface antigen; HBc: hepatitis B core. 
TABLE II

Hepatitis B virus (HBV) serological status, HBV DNA positivity and HBV load of the patients

\begin{tabular}{|c|c|c|c|c|c|c|c|}
\hline \multirow[b]{2}{*}{$\begin{array}{l}\text { Serological } \\
\text { status }\end{array}$} & \multirow[b]{2}{*}{$\begin{array}{l}\text { HBV DNA } \\
\text { positivity (\%) }\end{array}$} & \multicolumn{3}{|c|}{ HBV load (copies/ml) } & \multicolumn{3}{|c|}{ Lamivudine treatment } \\
\hline & & Range & Mean & Median & $\begin{array}{l}\text { Number of } \\
\text { patients treated }\end{array}$ & $\begin{array}{l}\text { Duration } \\
\text { (months) }\end{array}$ & $\begin{array}{l}\text { HBV DNA } \\
\text { positivity }\end{array}$ \\
\hline HBsAg, anti-HBc & $8 / 12(67)$ & $9.0 \times 10^{6}$ to $6.6 \times 10^{9}$ & $2.5 \times 10^{9}$ & $3.5 \times 10^{9}$ & 8 & $11-48$ & $5 / 8$ \\
\hline Anti-HBc only & $3 / 10(30)$ & $2.2 \times 10^{4}$ to $1.2 \times 10^{6}$ & $4.2 \times 10^{5}$ & $3.0 \times 10^{4}$ & 7 & $11-48$ & $3 / 7$ \\
\hline Anti-HBs, anti-HBc & $3 / 22(14)$ & $1.2 \times 10^{4}$ to $3.2 \times 10^{5}$ & $3.8 \times 10^{5}$ & $5.0 \times 10^{4}$ & 16 & $36-60$ & $1 / 16$ \\
\hline Total & $14 / 44(39)$ & $1.2 \times 10^{4}$ to $6.6 \times 10^{9}$ & $1.2 \times 10^{9}$ & $1.1 \times 10^{7}$ & 31 & $11-60$ & 9/31 \\
\hline
\end{tabular}

HBsAg: hepatitis B surface antigen; HBc: hepatitis B core. The differences between HBV load mean and median values of HBsAg positive and negative patients were extremely significant $(\mathrm{p}<0.0001)$.

TABLE III

Hepatitis B virus (HBV) genotypes, HBV viral load and lamivudine polymerase resistant mutations

\begin{tabular}{|c|c|c|c|c|c|}
\hline Patient & HBV status & Genotype & $\begin{array}{c}\text { HBV DNA } \\
\text { level (copies/ml) }\end{array}$ & 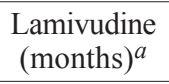 & Resistance mutations \\
\hline 3 & $\mathrm{HBsAg}$, anti-HBc & A & $6.6 \times 10^{9}$ & Yes (11) & L526M, M550V \\
\hline 4 & $\mathrm{HBsAg}$, anti-HBc & A & $5.4 \times 10^{9}$ & Yes (35) & L526M, M550V \\
\hline 10 & HBsAg, anti-HBc & $\mathrm{A}$ & $3.0 \times 10^{9}$ & No & - \\
\hline 12 & $\mathrm{HBsAg}$, anti-HBc & A & $6.0 \times 10^{8}$ & Yes (48) & L526M, M550V, V519L \\
\hline 13 & $\mathrm{HBsAg}$, anti-HBc & A & $2.0 \times 10^{7}$ & Yes (48) & No \\
\hline 16 & $\mathrm{HBsAg}$, anti-HBc & A & $9.0 \times 10^{6}$ & Yes (30) & No \\
\hline 8 & $\mathrm{HBsAg}$, anti-HBc & $\mathrm{D}$ & $4.0 \times 10^{9}$ & No & - \\
\hline 14 & HBsAg, anti-HBc & $\mathrm{D}$ & $1.3 \times 10^{7}$ & No & - \\
\hline 5 & Anti-HBs, anti-HBc & A & $3.2 \times 10^{5}$ & Yes $(50)$ & No \\
\hline 1 & Anti-HBs, anti-HBc & $\mathrm{D}$ & $1.2 \times 10^{4}$ & No & - \\
\hline 11 & Anti-HBs, anti-HBc & $\mathrm{D}$ & $5.0 \times 10^{4}$ & No & - \\
\hline 2 & Anti-HBc only & A & $1.2 \times 10^{6}$ & Yes (11) & No \\
\hline 6 & Anti-HBc only & A & $3.0 \times 10^{4}$ & Yes (48) & No \\
\hline 7 & Anti-HBc only & ND & $2.2 \times 10^{4}$ & Yes (36) & ND \\
\hline
\end{tabular}

$a$ : in parentheses, duration of lamivudine treatment; ND: not done.

for patients under lamivudine treatment but without lamivudine resistance mutations, with a highly significant difference $(p<0.0001)$ between the two groups.

\section{DISCUSSION}

Due to the shared modes of transmission of HBV and $\mathrm{HIV}$, the prevalence of HBV serological markers is higher among HIV infected patients than in non-HIV infected individuals (Hofer et al. 1998, Puoti et al. 2002). In a previous study conducted by us between 1998 and 2000, high prevalences of anti-HBc antibodies (68\%) and HBsAg (8\%) were observed among HIV infected patients living in Rio de Janeiro, Brazil (Santos et al. 2003). Comparison between the 44 patients from this study (2000 2004), and the group of 115 anti-HBc positive patients from the previous study (1998 2000) showed that the proportion of HBsAg positive patients was significantly higher in the present study ( 27 vs $12 \%, \mathrm{p}<0.05)$. Whether this increase constitutes a tendency should be confirmed by further studies. The proportion of women in this HIV infected patients with HBV serological markers augmented from 10 to $27 \%$, probably reflecting the major spread of HIV infection among women. Another significant change was the higher proportion of patients taking lamivudine as part of antiretroviral therapy (70 vs 34\%).
Occult hepatitis B virus infection has been studied in different populations. In a recent study conducted with HBsAg negative blood donors living in the South of Brazil, a region of low prevalence of $\mathrm{HBV}$ infection, a low rate $(3.3 \%)$ of occult infection among anti-HBc positive individuals was observed (Silva et al. 2005). However, occult hepatitis B has increasingly been detected in HIV positive patients in different parts of the world (Hofer et al. 1998, Grob et al. 2000, Shire \& Sherman 2005). Here, a proportion of $19 \%$ of HBV DNA positivity was observed among the HBsAg negative, anti-HBc positive, HIV infected patients. This proportion is similar to those found previously in Brazil (20\%; Santos et al. 2003), and South Africa (22\%; Mphahlele et al. 2006).

A number of explanations for the persistence of HBV DNA in HBsAg negative samples have been proposed, including the presence of HBV DNA at a low copy number (Brechot et al. 2001), genetic variations in the $\mathrm{S}$ gene (Carman 1997, Zuckerman 2000) and the presence of immune complexes in which HBsAg may be hidden (Liang et al. 1990, Ackerman et al. 1994). Occult hepatitis B may also be due to (i) the window period following acute HBV infection, (ii) poor laboratory detection of $\mathrm{HBsAg}$ due to low level of HBs antigenemia, (iii) underlying HCV coinfection, (iv) immunosuppression, or (v) other host fac- 
tors (Grob et al. 2000, Hu 2002). Moreover, it has been suggested recently that HIV infection may be a risk factor for occult hepatitis B (Mphahlele et al. 2006).

Our results show that the HBV DNA positivity rates and mean HBV load of the HBsAg positive patients were significantly higher when compared to HBsAg negative patients $(p<0.0001)$. These findings suggest that a low viral load might account for the lack of HBsAg detection in some patients, in accordance with other studies (Brechot et al. 2001, Santos et al. 2003). Since only six patients under study had HBV occult infection, no conclusion could be drawn about which patients were more prone to show this pattern of infection.

Suppression of HBV DNA by lamivudine treatment has been demonstrated in several studies performed with chronically HBV infected patients (reviewed in Karayiannis 2004, Locarnini 2004). In cases of HBV-HIV coinfected patients who received lamivudine as part of antiretroviral treatment, HBV DNA loss after one year of treatment was observed in $96.3 \%$ of patients when assessed by molecular hybridization and in $88.5 \%$ of patients by means of PCR (Benhamou et al. 1996). However, the main limitation of lamivudine therapy is the appearance of HBV resistant mutations during the therapy. Previous studies have demonstrated that the appearance of HBV lamivudine resistance is associated with prolonged lamivudine therapy (Liaw et al. 2000, Leung et al. 2001, Leung 2004). A rate of lamivudine resistance of $15-30 \%$ per year of therapy has been estimated (Leung 2004). In the present study, no significant difference was observed in relation to the prevalence of HBV DNA between the patients under lamivudine treatment and the others. This could be due to a high prevalence of lamivudine resistance mutations. Indeed all the patients under study who were taken lamivudine had done so for a relatively long period (ranging from 11 to 60 months), which could have lead to the emergence of lamivudine resistance. Among the 10 individuals receiving lamivudine, only three (30\%) developed lamivudine-resistance associated mutations. All three isolates were from $\mathrm{HBsAg}$ positive patients. In contrast, all isolates from HBsAg negative samples did not display lamivudine resistance mutations. In another study involving HBsAg positive, HIV infected patients almost $50 \%$ of patients who were HBV DNA positive did not display lamivudine resistance mutations (Cooley et al. 2003). Furthermore, these patients and those with resistance mutations had been under lamivudine therapy for a similar period of time. In that study and in ours, it remains unclear why a high proportion of HBV DNA positive patients did not develop lamivudine resistance

The low frequency of resistance mutations observed here in viremic patients may be associated with occult infection or with the asymptomatic state of the HBV infection. Recently, a low (3.1\%) frequency of HBV lamivudine resistance mutants was observed among asymptomatic HBV carriers receiving prophylactic lamivudine during chemotherapy for hematological malignancies (Pelizzari et al. 2004). In any case, the low HBV viremia itself may be an escape mechanism from the drug. In the present study, indeed, patients without resistance mutations had a lower mean viral load than patients with resis- tance mutations $(\mathrm{p}<0.0001)$.

Two isolates displayed the L526M and M550V mutations. In addition, one sample displayed a third, previously described (Torresi et al. 2002, Cooley et al. 2003) lamivudine resistance mutation, namely V519L. The triple mutation V519L/L526M/ M550V causes the concomitant amino acid substitutions E164D and I195M in the S protein. It has been shown recently that this triple mutant has a reduced affinity to anti-HBs antibodies, similarly to what happens with the well-known hepatitis B vaccine escape mutant G145R (Torresi et al. 2002, Cooley et al. 2003).

In conclusion, a high frequency of HBV occult infection was found among Brazilian HIV infected patients. No lamivudine resistance mutation was observed in case of occult HBV infection.

\section{ACKNOWLEDGMENTS}

To Dr Alan Kay for his valuable comments and for English revision. To the sequencing platform of the PDTIS program from Fiocruz for performing the DNA sequencing.

\section{REFERENCES}

Ackerman Z, Wands JR, Gazitt Y, Brechot C, Kew MC, Shouval D 1994. Enhancement of HBsAg detection in serum of patients with chronic liver disease following removal of circulating immune complexes. J Hepatol 20: 398-404.

Allain JP 2004. Occult hepatitis B virus infection: implications in transfusion. Vox Sang 86: 83-91.

Araujo NM, Mello FC, Yoshida CF, Niel C, Gomes SA 2004. High proportion of subgroup A' (genotype A) among Brazilian isolates of Hepatitis B virus. Arch Virol 149: 13831395.

Benhamou Y, Katlama C, Lunel F, Coutellier A, Dohin E, Hamm N, Tubiana R, Herson S, Poynard T, Opolon P 1996. Effects of lamivudine on replication of hepatitis B virus in HIV-infected men. Ann Intern Med 125: 705-712.

Brechot C, Thiers V, Kremsdorf D, Nalpas B, Pol S, PaterliniBrechot P 2001. Persistent hepatitis B virus infection in subjects without hepatitis B surface antigen: clinically significant or purely "occult"? Hepatology 34: 194-203.

Carman WF 1997. The clinical significance of surface antigen variants of hepatitis B virus. J Viral Hepat 4 (Suppl. 1): 1120.

Conjeevaram HS, Lok AS 2001. Occult hepatitis B virus infection: a hidden menace? Hepatology 34: 204-206.

Cooley L, Ayres A, Bartholomeusz A, Lewin S, Crowe S, Mijch A, Locarnini S, Sasadeusz J 2003. Prevalence and characterization of lamivudine-resistant hepatitis B virus mutations in HIV-HBV co-infected individuals. Aids 17: 16491657.

Dienstag JL, Perrillo RP, Schiff ER, Bartholomew M, Vicary C, Rubin M 1995. A preliminary trial of lamivudine for chronic hepatitis B infection. N Engl J Med 333: 1657-1661.

Dore GJ, Cooper DA, Barrett C, Goh LE, Thakrar B, Atkins M 1999. Dual efficacy of lamivudine treatment in human immunodeficiency virus/hepatitis B virus-coinfected persons in a randomized, controlled study (CAESAR). The CAESAR Coordinating Committee. J Infect Dis 180: 607-613. 
Grob P, Jilg W, Bornhak H, Gerken G, Gerlich W, Gunther S, Hess G, Hudig H, Kitchen A, Margolis H, Michel G, Trepo C, Will H, Zanetti A, Mushahwar I 2000. Serological pattern "anti-HBc alone": report on a workshop. J Med Virol 62: 450-455.

Hofer M, Joller-Jemelka HI, Grob PJ, Luthy R, Opravil M 1998. Frequent chronic hepatitis B virus infection in HIVinfected patients positive for antibody to hepatitis B core antigen only. Swiss HIV Cohort Study. Eur J Clin Microbiol Infect Dis 17: 6-13.

Hoff J, Bani-Sadr F, Gassin M, Raffi F 2001. Evaluation of chronic hepatitis B virus (HBV) infection in coinfected patients receiving lamivudine as a component of anti-human immunodeficiency virus regimens. Clin Infect Dis 32: 963-969.

Hu KQ 2002. Occult hepatitis B virus infection and its clinical implications. J Viral Hepat 9: 243-257.

Karayiannis P 2004. Current therapies for chronic hepatitis B virus infection. Expert Rev Anti Infect Ther 2: 745-760.

Koibuchi T, Hitani A, Nakamura T, Nojiri N, Nakajima K, Jyuji T, Iwamoto A 2001. Predominance of genotype A HBV in an HBV-HIV-1 dually positive population compared with an HIV-1-negative counterpart in Japan. J Med Virol 64: $435-440$.

Lai CL, Yuen MF 2000. Profound suppression of hepatitis B virus replication with lamivudine. J Med Virol 61: 367-373.

Leung N 2004. Lamivudine for chronic hepatitis B. Expert Rev Anti Infect Ther 2: 173-180.

Leung NW, Lai CL, Chang TT, Guan R, Lee CM, Ng KY, Lim SG, Wu PC, Dent JC, Edmundson S, Condreay LD, Chien RN 2001. Extended lamivudine treatment in patients with chronic hepatitis B enhances hepatitis B e antigen seroconversion rates: results after 3 years of therapy. Hepatology 33: 1527-1532.

Liang TJ, Blum HE, Wands JR 1990. Characterization and biological properties of a hepatitis B virus isolated from a patient without hepatitis B virus serologic markers. Hepatology 12: 204-212.

Liaw YF, Leung NW, Chang TT, Guan R, Tai DI, Ng KY, Chien RN, Dent J, Roman L, Edmundson S, Lai CL 2000. Effects of extended lamivudine therapy in Asian patients with chronic hepatitis B. Asia Hepatitis Lamivudine Study Group. Gastroenterology 119: 172-180.

Locarnini S 2004. Molecular virology of hepatitis B virus. Semin Liver Dis 24 (Suppl. 1): 3-10.

Loriot MA, Marcellin P, Bismuth E, Martinot-Peignoux M, Boyer N, Degott C, Erlinger S, Benhamou JP 1992. Demonstration of hepatitis B virus DNA by polymerase chain reaction in the serum and the liver after spontaneous or therapeutically induced $\mathrm{HBeAg}$ to anti-HBe or $\mathrm{HBsAg}$ to anti-HBs seroconversion in patients with chronic hepatitis B. Hepatology 15: 32-36.

Medrano FJ, Sanchez-Quijano A, Pineda J, Lissen E 1991. Isolated anti-HBc and hepatitis B virus occult infection. Vox Sang 61: 140 .

Moraes MT, Gomes SA, Niel C 1996. Sequence analysis of pre-S/S gene of hepatitis B virus strains of genotypes A, D, and F isolated in Brazil. Arch Virol 141: 1767-1773.
Mphahlele MJ, Lukhwareni A, Burnett RJ, Moropeng LM, Ngobeni JM 2006. High risk of occult hepatitis B virus infection in HIV-positive patients from South Africa. J Clin Virol 35: 14-20.

Niel C, Moraes MT, Gaspar AM, Yoshida CF, Gomes SA 1994. Genetic diversity of hepatitis B virus strains isolated in Rio de Janeiro, Brazil. J Med Virol 44: 180-186.

Niesters HG, Krajden M, Cork L, de Medina M, Hill M, Fries E, Osterhaus AD 2000. A multicenter study evaluation of the digene hybrid capture II signal amplification technique for detection of hepatitis B virus DNA in serum samples and testing of EUROHEP standards. J Clin Microbiol 38: 2150-2155.

Pas SD, Niesters HG 2002. Detection of HBV DNA using real time analysis. J Clin Virol 25: 93-94.

Pelizzari AM, Motta M, Cariani E, Turconi P, Borlenghi E, Rossi G 2004. Frequency of hepatitis B virus mutant in asymptomatic hepatitis B virus carriers receiving prophylactic lamivudine during chemotherapy for hematologic malignancies. Hematol J 5: 325-328.

Puoti M, Airoldi M, Bruno R, Zanini B, Spinetti A, Pezzoli C, Patroni A, Castelli F, Sacchi P, Filice G, Carosi G 2002. Hepatitis B virus co-infection in human immunodeficiency virus-infected subjects. AIDS Rev 4: 27-35.

Santos EA, Sucupira MV, Arabe J, Gomes SA 2004. Hepatitis $B$ virus variants in an HIV-HBV co-infected patient at different periods of antiretroviral treatment with and without lamivudine. BMC Infect Dis 4: 29.

Santos EA, Yoshida CF, Rolla VC, Mendes JM, Vieira IF, Arabe J, Gomes SA 2003. Frequent occult hepatitis B virus infection in patients infected with human immunodeficiency virus type 1. Eur J Clin Microbiol Infect Dis 22: 92-98.

Shire NJ, Sherman KE 2005. Management of HBV/HIVCoinfected Patients. Semin Liver Dis 25 (Suppl. 1): 48-57.

Silva CM, Costi C, Costa C, Michelon C, Oravec R, Ramos AB, Niel C, Rossetti ML 2005. Low rate of occult hepatitis $B$ virus infection among anti-HBc positive blood donors living in a low prevalence region in Brazil. J Infect 51: 2429.

Thibault V, Benhamou Y, Seguret C, Bochet M, Katlama C, Bricaire F, Opolon P, Poynard T, Agut H 1999. Hepatitis B virus (HBV) mutations associated with resistance to lamivudine in patients coinfected with HBV and human immunodeficiency virus. J Clin Microbiol 37: 3013-3016.

Thio CL 2004. Management of chronic hepatitis B in the HIVinfected patient. AIDS Read 14: 122-129, 133, 136-137.

Torresi J, Earnest-Silveira L, Deliyannis G, Edgtton K, Zhuang H, Locarnini SA, Fyfe J, Sozzi T, Jackson DC 2002. Reduced antigenicity of the hepatitis B virus HBsAg protein arising as a consequence of sequence changes in the overlapping polymerase gene that are selected by lamivudine therapy. Virology 293: 305-313.

Yeh CT, Chien RN, Chu CM, Liaw YF 2000. Clearance of the original hepatitis B virus YMDD-motif mutants with emergence of distinct lamivudine-resistant mutants during prolonged lamivudine therapy. Hepatology 31: 1318-1326.

Zuckerman AJ 2000. Effect of hepatitis B virus mutants on efficacy of vaccination. Lancet 355: 1382-1384. 